\title{
Synthesis and biological evaluation of sulfonamide thiazole and benzothiazole derivatives as antimicrobial agents
}

\author{
Iro Argyropoulou, ${ }^{a}$ Athina Geronikaki, ${ }^{a} *$ Paola Vicini, ${ }^{b}$ and Franca Zani ${ }^{b}$ \\ ${ }^{a}$ Department of Pharmaceutical Chemistry, School of Pharmacy, Aristotelian University of \\ Thessaloniki, Thessaloniki 54006, Greece \\ ${ }^{b}$ Dipartimento Farmaceutico, Universita`degli Studi di Parma, Viale G. P. Usberti 27/A, Parma \\ 43100, Italy \\ E-mail: geronik@pharm.auth.gr
}

\section{Dedicated to $80^{\text {th }}$ anniversary of Prof. Henk Van der Plas}

\begin{abstract}
Several thiazoles and benzothiazoles carrying a benzenesulfonamide moiety at position 2 of the heterocyclic nucleus were synthesised and tested as antimicrobial agents. All sulfanilamides and some of the nitro substituted sulfonamides have effective antibacterial properties against Gram positive bacteria (MIC $0.3-100 \mu \mathrm{g} / \mathrm{mL}$ ) such as several bacilli, staphylococci and streptococci, including methicillin-resistant Staphylococcus aureus and Staphylococcus epidermidis strains. On the contrary, no inhibition of Gram negative Escherichia coli and fungi is detected up to the concentration of $100 \mu \mathrm{g} / \mathrm{mL}$. Synergistic inhibitory activity occurs when the active antibacterial sulfonamides are tested in combination with trimethoprim against both Bacillus subtilis and Staphylococcus aureus.
\end{abstract}

Keywords: Thiazole derivatives, benzothiazole derivatives, sulfonamides, antimicrobial activity

\section{Introduction}

It is well-known that the thiazolyl group is of great importance in biological systems. Alkyl/arylaminoacetyl derivatives of 2-amino-4-phenylthiazolyl, ${ }^{1} \quad 2$-aminobenzothiazolyl, ${ }^{2}$ 2amino(substituted)-benzothiazolyl, ${ }^{3} \quad$ 2-phenylamino-4-phenylthiazolyl, ${ }^{4} \quad$ 2-amino-4methylthiazolyl, ${ }^{5}$ as well as 3 -aminobenzo[ $[d]$ isothiazole derivatives ${ }^{6}$ were found to have a potent local anaesthetic activity. Anti-inflammatory, analgesic, and antipyretic activities for some thiazolyl and benzothiazolyl derivatives are also known. ${ }^{7,8}$

On the other hand, sulfonamides have a variety of biological activities such as antibacterial, ${ }^{9-11}$ insulin releasing, ${ }^{12}$ carbonic anhydrase inhibitory, ${ }^{13,14}$ anti-inflammatory, ${ }^{15}$ and 
antitumor $^{16}$ activities. These findings encouraged us to explore the synthesis of sulfonamides containing thiazole/benzothiazole moieties and to examine their antibacterial and antifungal properties.

The compounds synthesized for this study are shown in Figure $1 .{ }^{17-23}$ Here we report the synthesis of the above compounds and the evaluation of their antimicrobial activity.
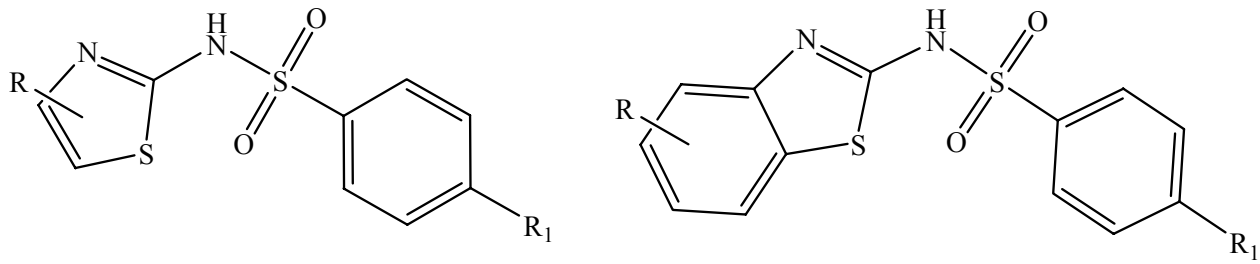

\begin{tabular}{l|l|l} 
Comp. & $\mathrm{R}$ & $\mathrm{R}_{1}$ \\
\hline $\mathbf{1}^{17}$ & $5-\mathrm{CH}_{3}$ & $\mathrm{NH}_{2}$ \\
$\mathbf{2}^{18}$ & $\mathrm{H}$ & $\mathrm{NO}_{2}$ \\
$\mathbf{3}^{19}$ & $4-\mathrm{CH}_{3}$ & $\mathrm{NO}_{2}$ \\
$\mathbf{4}^{20}$ & $4-\mathrm{CH}_{2} \mathrm{COOC}_{2} \mathrm{H}_{5}$ & $\mathrm{NO}_{2}$ \\
$\mathbf{5}^{21}$ & $\mathrm{H}$ & $\mathrm{CH}_{3}$
\end{tabular}

\begin{tabular}{l|l|l} 
Comp. & $\mathrm{R}$ & $\mathrm{R}_{1}$ \\
\hline $\mathbf{6}^{22}$ & $4-\mathrm{CH}_{3}$ & $\mathrm{NH}_{2}$ \\
$\mathbf{7}^{22}$ & $6-\mathrm{Cl}$ & $\mathrm{NH}_{2}$ \\
$\mathbf{8}^{17}$ & $6-\mathrm{OC} \mathrm{H}_{5}$ & $\mathrm{NH}_{2}$ \\
$\mathbf{9}^{18}$ & $\mathrm{H}$ & $\mathrm{NO}_{2}$ \\
$\mathbf{1 0}$ & $4-\mathrm{CH}_{3}$ & $\mathrm{NO}_{2}$ \\
$\mathbf{1 1}$ & $6-\mathrm{OC}_{2} \mathrm{H}_{5}$ & $\mathrm{NO}_{2}$ \\
$\mathbf{1 2}$ & $6-\mathrm{F}$ & $\mathrm{NO}_{2}$ \\
$\mathbf{1 3}$ & $6-\mathrm{Cl}$ & $\mathrm{NO}_{2}$ \\
$\mathbf{1 4}$ & $\mathrm{H}$ & $\mathrm{Cl}$ \\
$\mathbf{1 5}$ & $6-\mathrm{Cl}$ & $\mathrm{Cl}$
\end{tabular}

Figure 1. Structure of the synthesized compounds.

\section{Results and Discussion}

\section{Chemistry}

The general method which is employed to prepare the final compounds is outlined in Scheme 1.

The designed sulfonamides were prepared by heating the appropriate heteroarylamine with the selected benzensulfonylchlorides in pyridine for several hours. Nucleophilic addition of the $\mathrm{NH}_{2}$ group to the sulfonyl function of the benzenlsulfonylchlorides takes place. Difficulties connected with the poor reactivity of some starting materials were overcome by increasing the duration of heating. 4-Aminobenzenesulfonamides $\mathbf{1}$ and 6-8 were prepared from the corresponding 4-acetamidobenzenesulfonamides by refluxing the last one in ethanol containing small amount of concentrated $\mathrm{HCl}$.

During the course of this study we obtained some sulfonamides in good yield and some others in moderate to low. The structures of the synthesized compounds were confirmed by elemental analysis and by MS, IR and ${ }^{1} \mathrm{H}$ NMR spectral data. 


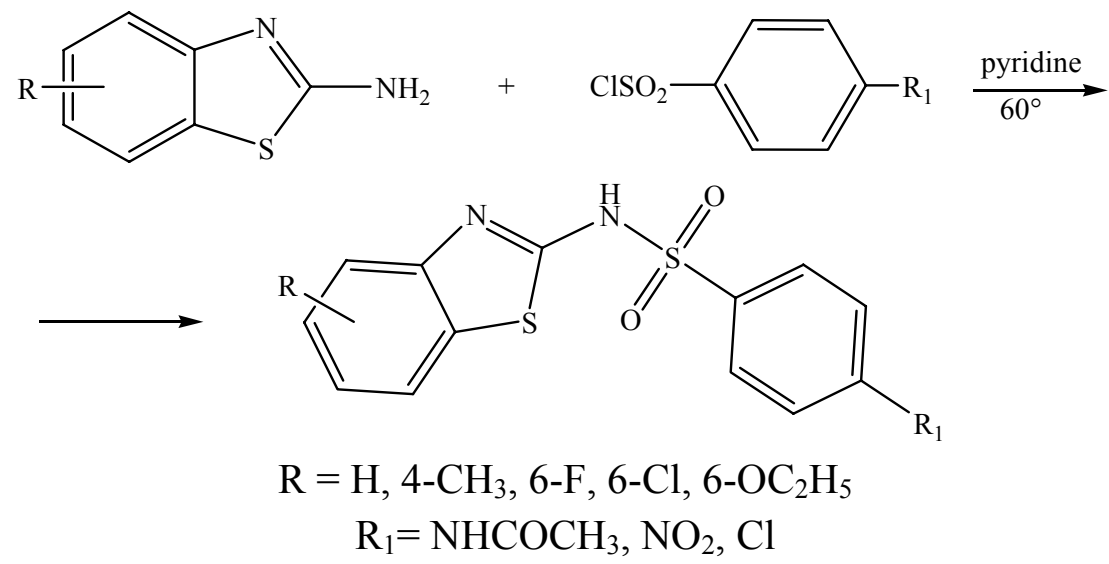

\section{Scheme 1}

\section{Antimicrobial activity}

The thiazole/benzothiazole sulfonamides were assayed in vitro for their antimicrobial activity against a panel of selected Gram positive and Gram negative bacteria, yeasts and mould and the minimal inhibitory concentrations that inhibited the growth of the tested microorganisms (MIC) were detected. In order to elucidate the kind of the exhibited antimicrobial activity, when MIC values were lower than $100 \mu \mathrm{g} / \mathrm{mL}$, the minimal bactericidal concentrations (MBCs) and the minimal fungicidal concentrations (MFCs) were determined. The results of antimicrobial testing are reported in Table 1 and are compared with those of standards ampicillin and sulfamethoxazole as antibacterial agents and miconazole as an antifungal drug.

Table 1. Antimicrobial activity expressed as $\mathrm{MIC}(\mu \mathrm{g} / \mathrm{mL})$ and, in brackets, as $\mathrm{MBC}$ and $\mathrm{MFC}$ $(\mu \mathrm{g} / \mathrm{mL})$

\begin{tabular}{|c|c|c|c|c|c|c|}
\hline \multirow[b]{2}{*}{ Compound } & \multicolumn{3}{|l|}{ Bacteria $^{\mathrm{a}}$} & \multicolumn{3}{|l|}{ Fungi $^{\mathrm{b}}$} \\
\hline & $\mathrm{BS}$ & SA & $\mathrm{EC}$ & $\mathrm{SC}$ & $\mathrm{CT}$ & AN \\
\hline 1 & $\begin{array}{c}12 \\
(50)\end{array}$ & $\begin{array}{c}50 \\
(>100)\end{array}$ & $\begin{array}{l}>100 \\
(n a)^{d}\end{array}$ & $\begin{array}{c}>100 \\
\text { (na) }\end{array}$ & $\begin{array}{c}>100 \\
\text { (na) }\end{array}$ & $\begin{array}{l}>100 \\
\text { (na) }\end{array}$ \\
\hline & $\mathrm{S}^{\mathrm{c}}$ & $\mathrm{S}$ & & & & \\
\hline 2 & $\begin{array}{c}25 \\
(>100)\end{array}$ & $\begin{array}{c}>100 \\
\text { (na) }\end{array}$ & $\begin{array}{c}>100 \\
\text { (na) }\end{array}$ & $\begin{array}{c}>100 \\
\text { (na) }\end{array}$ & $\begin{array}{c}>100 \\
\text { (na) }\end{array}$ & $\begin{array}{l}>100 \\
\text { (na) }\end{array}$ \\
\hline & $\mathrm{S}$ & & & & & \\
\hline 3 & $\begin{array}{c}>100 \\
\text { (na) }\end{array}$ & $\begin{array}{c}>100 \\
\text { (na) }\end{array}$ & $\begin{array}{c}>100 \\
\text { (na) }\end{array}$ & $\begin{array}{c}>100 \\
\text { (na) }\end{array}$ & $\begin{array}{c}>100 \\
\text { (na) }\end{array}$ & $\begin{array}{r}>100 \\
\text { (na) }\end{array}$ \\
\hline 4 & $\begin{array}{c}12 \\
(>100)\end{array}$ & $\begin{array}{c}>100 \\
\text { (na) }\end{array}$ & $\begin{array}{c}>100 \\
\text { (na) }\end{array}$ & $\begin{array}{c}>100 \\
\text { (na) }\end{array}$ & $\begin{array}{c}>100 \\
\text { (na) }\end{array}$ & $\begin{array}{l}>100 \\
\text { (na) }\end{array}$ \\
\hline
\end{tabular}




\begin{tabular}{|c|c|c|c|c|c|c|}
\hline 5 & $\begin{array}{c}>100 \\
\text { (na) }\end{array}$ & $\begin{array}{c}>100 \\
\text { (na) }\end{array}$ & $\begin{array}{c}>100 \\
\text { (na) }\end{array}$ & $\begin{array}{c}>100 \\
(\mathrm{na})\end{array}$ & $\begin{array}{c}>100 \\
\text { (na) }\end{array}$ & $\begin{array}{c}>100 \\
\text { (na) }\end{array}$ \\
\hline \multirow[t]{2}{*}{6} & $\begin{array}{c}1.5 \\
(12)\end{array}$ & $\begin{array}{c}12 \\
(50)\end{array}$ & $\begin{array}{c}>100 \\
\text { (na) }\end{array}$ & $\begin{array}{c}>100 \\
\text { (na) }\end{array}$ & $\begin{array}{c}>100 \\
\text { (na) }\end{array}$ & $\begin{array}{c}>100 \\
\text { (na) }\end{array}$ \\
\hline & $\mathrm{S}$ & $\mathrm{S}$ & & & & \\
\hline \multirow[t]{2}{*}{7} & $\begin{array}{c}12 \\
(100)\end{array}$ & $\begin{array}{c}25 \\
(>100)\end{array}$ & $\begin{array}{c}>100 \\
\text { (na) }\end{array}$ & $\begin{array}{c}>100 \\
\text { (na) }\end{array}$ & $\begin{array}{c}>100 \\
\text { (na) }\end{array}$ & $\begin{array}{c}>100 \\
\text { (na) }\end{array}$ \\
\hline & $\mathrm{S}$ & $\mathrm{S}$ & & & & \\
\hline \multirow[t]{2}{*}{8} & $\begin{array}{c}3 \\
(25)\end{array}$ & $\begin{array}{c}12 \\
(50)\end{array}$ & $\begin{array}{c}>100 \\
\text { (na) }\end{array}$ & $\begin{array}{c}>100 \\
\text { (na) }\end{array}$ & $\begin{array}{c}>100 \\
\text { (na) }\end{array}$ & $\begin{array}{c}>100 \\
\text { (na) }\end{array}$ \\
\hline & $\mathrm{S}$ & $\mathrm{S}$ & & & & \\
\hline \multirow[t]{2}{*}{9} & $\begin{array}{c}12 \\
(50)\end{array}$ & $\begin{array}{c}>100 \\
\text { (na) }\end{array}$ & $\begin{array}{c}>100 \\
\text { (na) }\end{array}$ & $\begin{array}{c}>100 \\
\text { (na) }\end{array}$ & $\begin{array}{c}>100 \\
\text { (na) }\end{array}$ & $\begin{array}{c}>100 \\
\text { (na) }\end{array}$ \\
\hline & $\mathrm{S}$ & & & & & \\
\hline \multirow[t]{2}{*}{10} & $\begin{array}{c}25 \\
(>100)\end{array}$ & $\begin{array}{c}50 \\
(>100)\end{array}$ & $\begin{array}{c}>100 \\
\text { (na) }\end{array}$ & $\begin{array}{c}>100 \\
\text { (na) }\end{array}$ & $\begin{array}{c}>100 \\
\text { (na) }\end{array}$ & $\begin{array}{c}>100 \\
\text { (na) }\end{array}$ \\
\hline & $\mathrm{S}$ & $\mathrm{S}$ & & & & \\
\hline 11 & $\begin{array}{c}>100 \\
\text { (na) }\end{array}$ & $\begin{array}{c}>100 \\
\text { (na) }\end{array}$ & $\begin{array}{c}>100 \\
\text { (na) }\end{array}$ & $\begin{array}{c}>100 \\
\text { (na) }\end{array}$ & $\begin{array}{c}>100 \\
\text { (na) }\end{array}$ & $\begin{array}{c}>100 \\
\text { (na) }\end{array}$ \\
\hline 12 & $\begin{array}{c}>100 \\
\text { (na) }\end{array}$ & $\begin{array}{c}>100 \\
\text { (na) }\end{array}$ & $\begin{array}{c}>100 \\
\text { (na) }\end{array}$ & $\begin{array}{c}>100 \\
\text { (na) }\end{array}$ & $\begin{array}{c}>100 \\
\text { (na) }\end{array}$ & $\begin{array}{c}>100 \\
\text { (na) }\end{array}$ \\
\hline 13 & $\begin{array}{c}>100 \\
\text { (na) }\end{array}$ & $\begin{array}{c}>100 \\
\text { (na) }\end{array}$ & $\begin{array}{c}>100 \\
\text { (na) }\end{array}$ & $\begin{array}{c}>100 \\
\text { (na) }\end{array}$ & $\begin{array}{c}>100 \\
(\mathrm{na})\end{array}$ & $\begin{array}{c}>100 \\
\text { (na) }\end{array}$ \\
\hline 14 & $\begin{array}{l}>100 \\
\text { (na) }\end{array}$ & $\begin{array}{c}>100 \\
\text { (na) }\end{array}$ & $\begin{array}{l}>100 \\
\text { (na) }\end{array}$ & $\begin{array}{c}>100 \\
\text { (na) }\end{array}$ & $\begin{array}{c}>100 \\
\text { (na) }\end{array}$ & $\begin{array}{c}>100 \\
\text { (na) }\end{array}$ \\
\hline 15 & $\begin{array}{c}>100 \\
\text { (na) }\end{array}$ & $\begin{array}{c}>100 \\
\text { (na) }\end{array}$ & $\begin{array}{c}>100 \\
\text { (na) }\end{array}$ & $\begin{array}{c}>100 \\
\text { (na) }\end{array}$ & $\begin{array}{c}>100 \\
\text { (na) }\end{array}$ & $\begin{array}{c}>100 \\
\text { (na) }\end{array}$ \\
\hline Sulfamethoxazole & $\begin{array}{c}6 \\
(25)\end{array}$ & $\begin{array}{c}25 \\
(100)\end{array}$ & $\begin{array}{c}>100 \\
\text { (na) }\end{array}$ & $\begin{array}{c}>100 \\
\text { (na) }\end{array}$ & $\begin{array}{c}>100 \\
\text { (na) }\end{array}$ & $\begin{array}{c}>100 \\
\text { (na) }\end{array}$ \\
\hline Ampicillin & $\begin{array}{l}0.007 \\
(0.15)\end{array}$ & $\begin{array}{l}0.07 \\
(1.5)\end{array}$ & $\begin{array}{c}3 \\
(25)\end{array}$ & $-{ }^{e}$ & - & - \\
\hline Miconazole & - & - & - & $\begin{array}{c}12 \\
(25)\end{array}$ & $\begin{array}{c}6 \\
(25)\end{array}$ & $\begin{array}{c}3 \\
(12)\end{array}$ \\
\hline
\end{tabular}

${ }^{\mathrm{a}}$ Gram positive bacteria: Bacillus subtilis ATCC 6633 (BS) and Staphylococcus aureus ATCC 25923 (SA); Gram negative bacteria: Escherichia coli SPA 27 (EC). ' ${ }^{\text {Yeasts: Saccharomyces }}$ cerevisiae ATCC 9763 (SC) and Candida tropicalis ATCC 1369 (CT); mould: Aspergillus niger ATCC 6275 (AN). ${ }^{c}$ Synergistic interaction with trimethoprim. ${ }^{\mathrm{d}}$ Not analyzed because MIC value is higher than $100 \mu \mathrm{g} / \mathrm{mL}$. ${ }^{\mathrm{e}}$ Not tested. 
Some of the tested compounds display good inhibition of the growth of Gram positive bacteria, being Bacillus subtilis the most sensitive one. It should be noted that compound 6 shows the best activity among all tested compound against Bacillus subtilis (MIC $1.5 \mu \mathrm{g} / \mathrm{mL}$ ) as well as Staphylococcus aureus (MIC $12 \mu \mathrm{g} / \mathrm{mL}$ ). Interesting results are also obtained for compound 8 towards the same microorganisms at 3 and $12 \mu \mathrm{g} / \mathrm{mL}$ respectively. These compounds are even more potent than sulfamethoxazole but less than ampicillin, while inhibitory properties comparable or slightly inferior to those of sulfamethoxazole are exhibited by compounds 1, 7 and $\mathbf{1 0}$ against both Gram positive bacteria and by compounds 2, 4 and 9 against Bacillus subtilis only.

Table 2. Spectrum of inhibitory activity of the most active compounds against Gram positive bacteria, expressed as MIC $(\mu \mathrm{g} / \mathrm{mL})$ and, in brackets, as $\mathrm{MBC}(\mu \mathrm{g} / \mathrm{mL})$

\begin{tabular}{|c|c|c|c|c|c|c|c|c|c|}
\hline \multirow[t]{2}{*}{ Microorganism $^{\mathrm{a}}$} & \multicolumn{9}{|c|}{ Compound } \\
\hline & 1 & 2 & 4 & 6 & 7 & 8 & 9 & 10 & $\mathbf{S M Z} \mathbf{Z}^{\mathbf{b}}$ \\
\hline \multirow[t]{2}{*}{$\mathrm{BM}$} & 3 & 25 & $>100$ & 1.5 & 3 & 0.3 & $>100$ & 25 & 1.5 \\
\hline & $(6)$ & $(50)$ & & (6) & (1)) & $(07)$ & & $(>10 n)$ & $(6)$ \\
\hline \multirow[t]{2}{*}{ BT } & 1.5 & 3 & $>100$ & 0.7 & 1.5 & 0.3 & $>100$ & 25 & 1.5 \\
\hline & (6) & (50) & & (3) & (6) & $(1.5)$ & & (100) & (12) \\
\hline \multirow[t]{2}{*}{ SL } & 1.5 & $>100$ & $>100$ & 0.3 & 0.3 & 0.3 & $>100$ & 50 & 0.7 \\
\hline & (12) & & & (6) & (1.5) & $(>100)$ & & $(>100)$ & (3) \\
\hline \multirow[t]{2}{*}{ SAMR } & 25 & $>100$ & $>100$ & 6 & 25 & $>100$ & $>100$ & 50 & 12 \\
\hline & (100) & & & (100) & (50) & & & $(>100)$ & $(50)$ \\
\hline \multirow[t]{2}{*}{ SE } & 50 & $>100$ & $>100$ & 12 & 6 & $>100$ & $>100$ & 25 & 50 \\
\hline & $(>100)$ & & & (50) & (25) & & & $(>100)$ & $(>100)$ \\
\hline \multirow[t]{2}{*}{ SEMR } & $>100$ & $>100$ & $>100$ & $>100$ & 6 & 100 & $>100$ & 12 & $>100$ \\
\hline & & & & & (25) & $(>100)$ & & (50) & \\
\hline \multirow[t]{2}{*}{ SH } & $>100$ & $>100$ & $>100$ & 12 & 12 & 50 & $>100$ & 50 & 25 \\
\hline & & & & (50) & (50) & $(>100)$ & & $(>100)$ & $(>100)$ \\
\hline \multirow[t]{2}{*}{ SAG } & 6 & $>100$ & $>100$ & 3 & 3 & $>100$ & $>100$ & $>100$ & 6 \\
\hline & (100) & & & (25) & (25) & & & & $(50)$ \\
\hline \multirow[t]{2}{*}{ SF } & $>100$ & $>100$ & $>100$ & $>100$ & 25 & $>100$ & $>100$ & $>100$ & $>100$ \\
\hline & & & & & $(>100)$ & & & & \\
\hline SU & $>100$ & $>100$ & $>100$ & $>100$ & $>100$ & $>100$ & $>100$ & $>100$ & $>100$ \\
\hline \multirow[t]{2}{*}{ SP } & 1.5 & 100 & $>100$ & 1.5 & 0.7 & $>100$ & $>100$ & 50 & 3 \\
\hline & (6) & $(>100)$ & & (12) & (12) & & & $(>100)$ & (25) \\
\hline
\end{tabular}

${ }^{a}$ Bacillus megaterium BGSC 7A2 (BM), Bacillus thuringiensis var. kurstaki BGSC 4D1 (BT), Sarcina lutea ATCC 9341 (SL) and clinical isolates of Staphylococcus aureus methicillin- 
resistant (SAMR), Staphylococcus epidermidis (SE), Staphylococcus epidermidis methicillinresistant (SEMR), Staphylococcus haemolyticus (SH), Streptococcus agalactiae (SAG), Streptococcus faecalis (SF), Streptococcus faecium (SU), Streptococcus pyogenes (SP). ${ }^{\mathrm{b}}$ Sulfamethoxazole.

The antimicrobial properties of the active compounds were further investigated towards a wide spectrum of Gram positive bacteria, including methicillin-resistant strains. Results, presented in Table 2, confirm the high inhibitory potency of compound $\mathbf{6}$ extended to all the tested bacilli, Sarcina, staphylococci and several streptococci at concentrations of $0.3-12 \mu \mathrm{g} / \mathrm{mL}$. Furthermore, sulfanilamides 1, 7 and $\mathbf{8}$ exhibit promising activity having a range of MIC values almost similar to that of sulfamethoxazole. A good inhibition can be observed also for nitro derivative 10 towards most of the tested bacteria and $\mathbf{2}$ towards bacilli. It is worth noting that some sulfonamides show significant activity also against methicillin-resistant Staphylococcus aureus and Staphylococcus epidermidis strains. The lack of activity of either compounds $\mathbf{4}$ and 9 in the extended spectrum studies makes these substances selective against Bacillus subtilis (Table 1).

In all the cases, MBC values are two-fold or more higher than MICs, suggesting that the effectiveness of these substances has a bacteriostatic character.

None of the tested compounds exhibits any activity against Gram negative Escherichia coli, yeasts Candida tropicalis and Saccharomyces cerevisiae, and mould Aspergillus niger up the concentration of $100 \mu \mathrm{g} / \mathrm{mL}$.

In addition, with the aim to investigate the action mechanism of the detected antibacterial activity, we evaluated by synergism studies the effectiveness of the new sulfonamides against the sensitive microorganisms in the presence of trimethoprim. It is, in fact, well-known that sulfonamides exert their antibacterial effect by inhibiting the biosynthesis of dihydrofolic acid and their activity is enhanced by the combination with trimethoprim, a competitive inhibitor of dihydrofolate reductase, an enzyme reducing dihydrofolic to tetrahydrofolic acid. ${ }^{24}$ So, both Bacillus subtilis and Staphylococcus aureus were used for sulfanilamides $\mathbf{1}$ and 6-8 and for the nitroderivative 10, while only Bacillus subtilis was used for compounds 2, 4 and 9. The results were, then, compared with the antibacterial activity of the substances used individually. Sulfamethoxazole-trimethoprim mixture was taken as positive control.

The paper strip diffusion determinations show that the antibacterial activity of all the tested sulfonamides is potentiated by trimethoprim. As evidenced in Figure 2, the size of inhibition zones of Bacillus subtilis is greatest where the compounds $\mathbf{4}$ and $\mathbf{6}$ overlap with trimethoprim, as observed for trimethoprim-sulfamethoxazole combination. A similar behaviour could be detected for compounds 1, 2 and 7-10 against the same microorganism and for compounds 1, 6-8 and 10 against Staphylococcus aureus (data not shown).

Since the paper strip test has a qualitative character, the antimicrobial synergism was then quantitatively assessed by the two fold dilution method in the checkerboard titration. Antibacterial sulfonamides plus trimethoprim were tested together in a large number of dilutions 
to determine the concentrations, of each compound in combination with trimethoprim, that inhibit the growth of Bacillus subtilis and Staphylococcus aureus. The interactions were detected in comparison with sulfamethoxazole-trimethoprim mixture and are described by the isobolograms of Figures 3 and 4. The obtained results confirm that subinhibitory concentrations of trimethoprim potentiate the antibacterial activity of all the tested compounds by strongly reducing their MIC values. Figures 3 and 4 exhibit concave isobols and fractional inhibitory concentration indices significantly lower than 0.5. In particular, FICIs range from 0.124 to 0.281 for Bacillus subtilis and from 0.124 to 0.312 for Staphylococcus aureus. This synergistic effect is comparable to that produced by the reference sulfamethoxazole-trimethoprim mixture and suggests that the studies sulfonamides act by inhibiting the synthesis of folic acid. ${ }^{24}$

SMZ

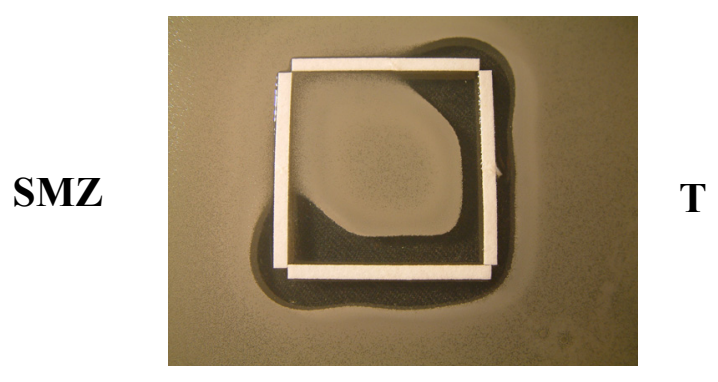

T
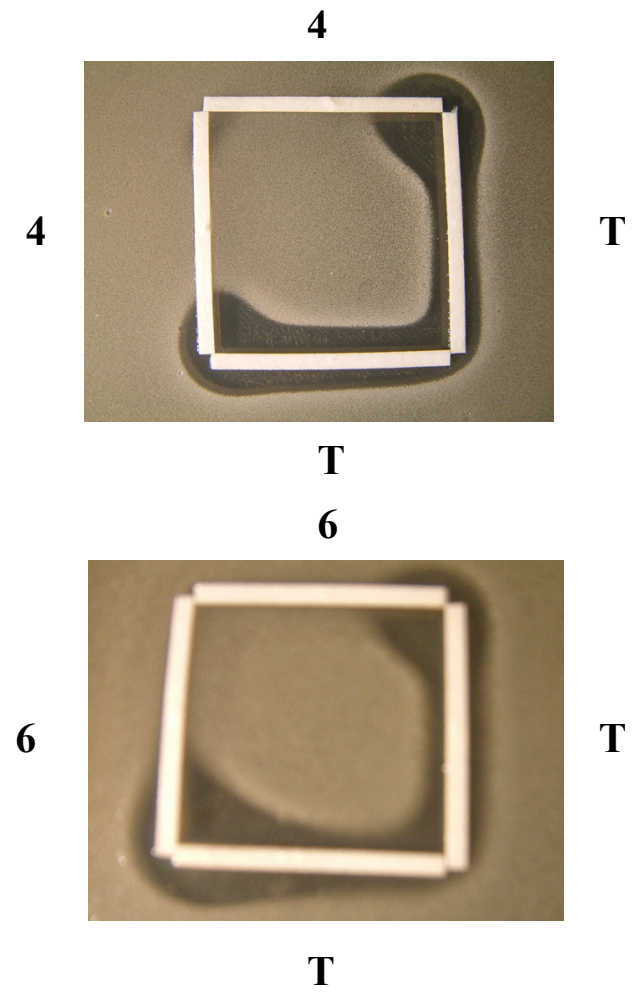

Figure 2. Susceptibility of Bacillus subtilis ATCC 6633 to combination of sulfamethoxazole (SMZ, $3 \mu \mathrm{g})$, compounds $4(10 \mu \mathrm{g})$ and $6(1.25 \mu \mathrm{g})$ with trimethoprim (T, $0.15 \mu \mathrm{g})$. 
(A)

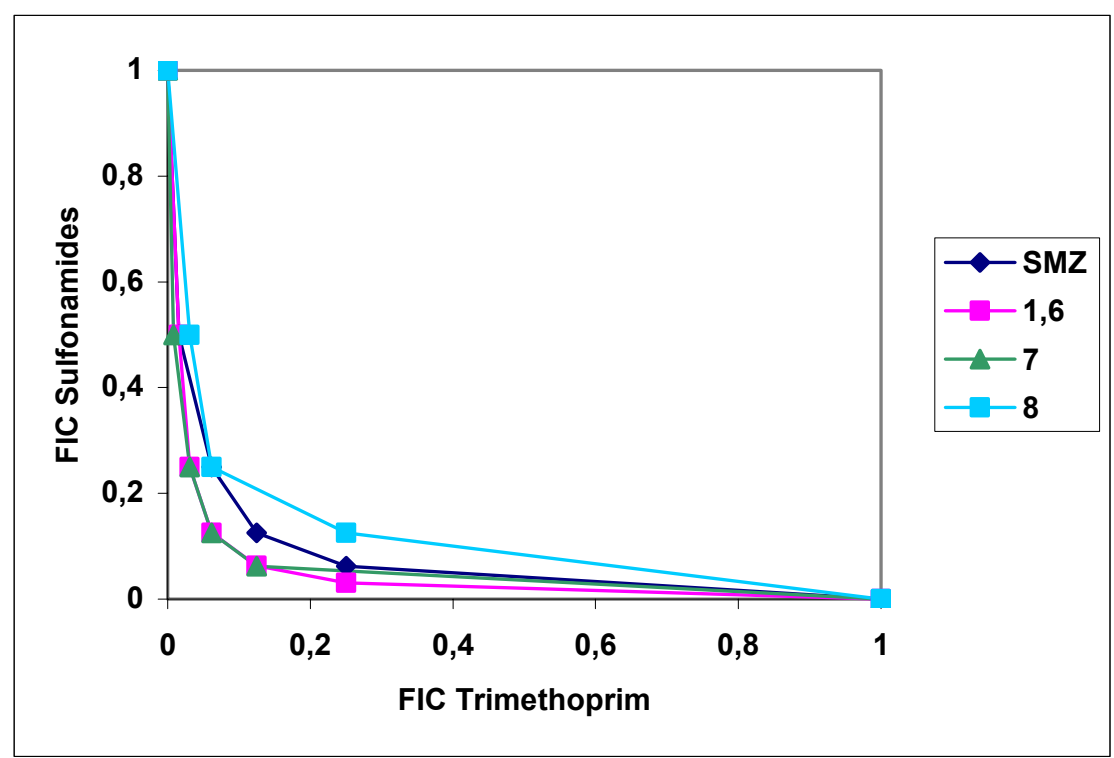

(B)

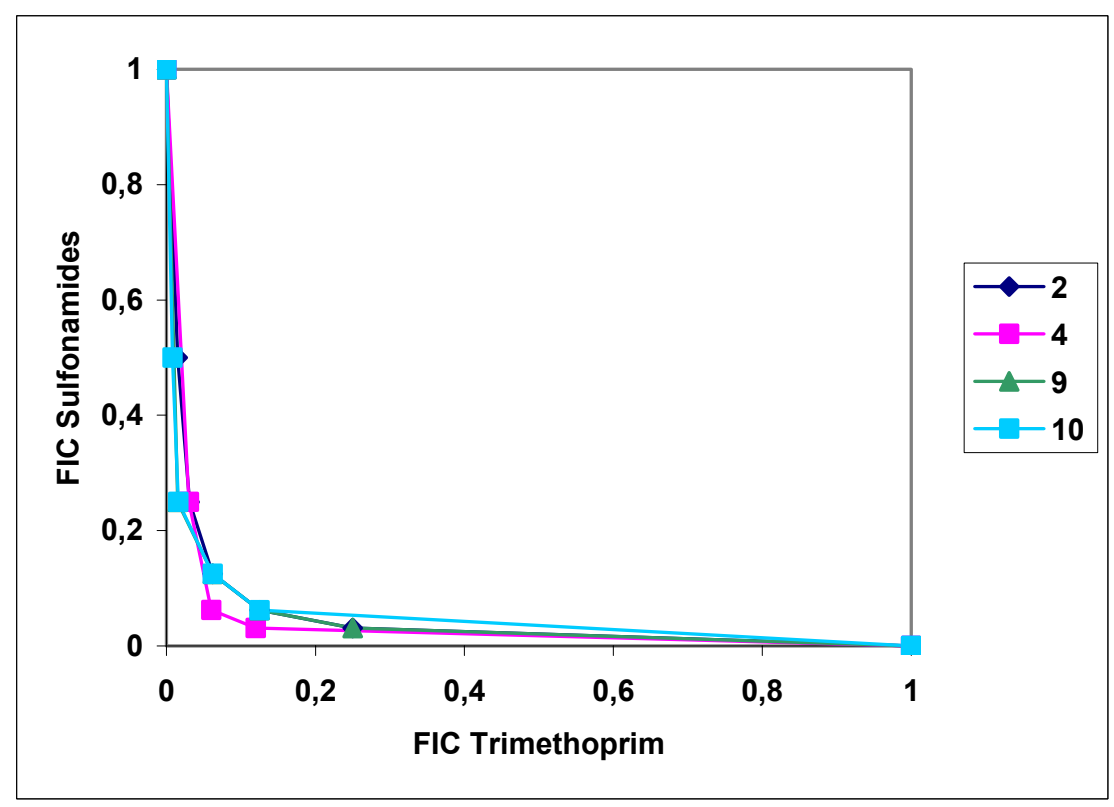

Figure 3. Assessment of combinations of sulfamethoxazole (SMZ), sulfanilamides 1 and 6-8 (A) and nitrosulfonamides 2, 4, 9 and 10 (B) with trimethoprim against Bacillus subtilis ATCC 6633 in the checkerboard broth dilution method. The concentrations of the drugs are expressed as fractions of the minimal inhibitory concentrations (FIC, fractional inhibitory concentration). 


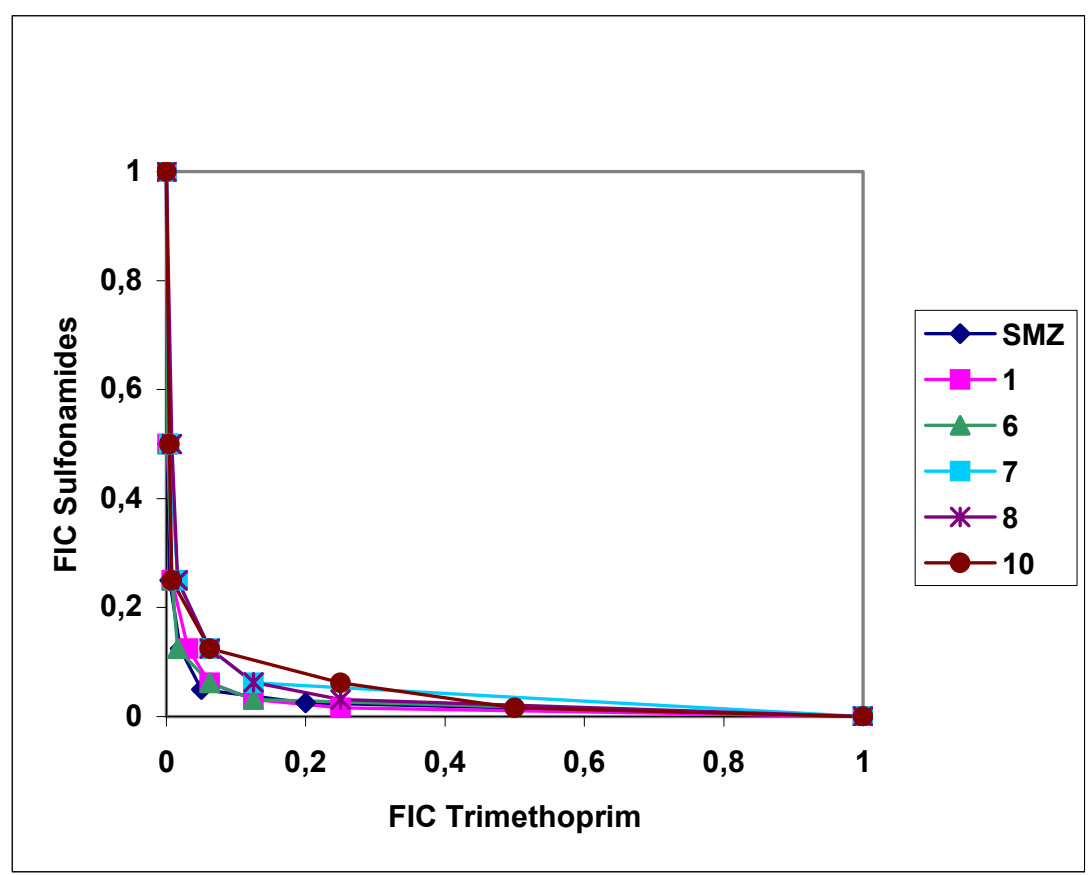

Figure 4. Assessment of combinations of sulfamethoxazole (SMZ), sulfanilamides 1, 6-8 and nitrosulfonamide 10 with trimethoprim against Staphylococcus aureus ATCC 25923 in the checkerboard broth dilution method. The concentrations of the drugs are expressed as fractions of the minimal inhibitory concentrations (FIC, fractional inhibitory concentration).

\section{Structure-activity relationship}

As regards the relationships between the structure of the heterocyclic scaffold and the detected antibacterial properties, it seems that there is no difference. Probably in this case the nature of the heterocyclic ring is not so important for antimicrobial activity. Moreover, the presence of substituents in different positions of both thiazole and benzothiazole moieties causes a certain change of activity. Among benzothiazoles, 4-amino- and 4-nitrosulfonamides having a halogen as substituent (compounds 7, 12 and 13) or carrying an ethoxy group (compounds 8 and 11) exhibit inhibitory properties lower than those of the corresponding methyl substituted ones (compounds 6 and 10, respectively). On the other hand, for the latter compound a decreased activity towards Bacillus subtilis and an enhancing inhibition of Staphylococcus aureus can be detected, when compared with unsubstituted compound 9. As concerns thiazole derivatives, the introduction in compound $\mathbf{2}$ of a lipophilic methyl group (compound 3) abolishes the activity against Bacillus subtilis, while the presence of a bulky group $\left(-\mathrm{CH}_{2} \mathrm{COOC}_{2} \mathrm{H}_{5}\right)$ in compound 4 does enhance its inhibition properties.

From the obtained results it is clear that the major role for antibacterial activity is played by the substituent in the 4-position of the aromatic ring of sulfonamides. It is evident that sulfonamides with an amino group in the C-4 position of the phenyl ring are the most active compounds. Thus, the replacement of the amino group with nitro leads to a dramatic decrease in 
antibacterial activity (compounds 6 and 10, 7 and 13, 8 and 11). No activity is exhibited by 4 chloro substituted sulfonamides $\mathbf{1 4}$ and $\mathbf{1 5}$ and by the 4-methyl derivative $\mathbf{5}$.

In addition, synergism studies suggest that an enzymatic reduction to amino derivatives involves the 4-nitrosulfonamides. ${ }^{25}$

\section{Experimental Section}

\section{Chemistry}

General Procedures. Melting points $\left(\mathrm{mp}^{\circ} \mathrm{C}\right)$ were determined with a Buchi 512 apparatus or with a Boetius apparatus and are uncorrected. Elemental analysis was performed on a ThermoQuest (Italia) FlashEA 1112 Elemental Analyser, for C, H, N, and S. The values found for C, H, N, S were within $\pm 0.4 \%$ of the theoretical ones. IR spectra, such as KBr pellets, were recorded on a Jasco FT-IR 300E spectrophotometer (Jasco Ltd., Tokyo, Japan). Mass spectra were recorded on a VG-250instrument (VG Labs Tritech, England) with ionization energy maintained. ${ }^{1} \mathrm{H}$ NMR spectra of the newly synthesized compounds, in DMSO-d $\mathrm{d}_{6}$ solutions, were recorded on a Bruker AC 300 instrument at $298{ }^{\circ} \mathrm{K}$. Chemical shifts are reported as $\delta$ (ppm) relative to TMS as internal standard; coupling constants $J$ are expressed in Hertz. The progress of the reactions was monitored by thin layer chromatography with $\mathrm{F}_{254}$ silica-gel precoated sheets (Merck, Darmstadt, Germany). UV light was used for detection.

Solvents, unless otherwise specified, were of analytical reagent grade or of the highest quality commercially available. Synthetic starting material, reagents and solvents were purchased from Aldrich Chemical Co. and from Fluka.

\section{General procedure for synthesis of thiazole/benzothiazole sulfonamides}

To the starting amine $(6 \mathrm{mmol})$ suspended in anhydrous pyridine $(10 \mathrm{~mL})$, appropriate sulfonyl chloride $(6.3 \mathrm{mmol})$ was added gradually. The reaction mixture was heated at $60^{\circ} \mathrm{C}$ for $1-4$ hours, then poured into ice water and acidified with $1 \mathrm{~N} \mathrm{HCl}$. The solid product was filtered, washed well with water, and recrystallized from ethanol.

\section{Hydrolysis of the intermediate $N$-(1,3-benzothiazol-3-yl)-4-acetaminobenzenesulfonamides}

The crude acetyl derivative was refluxed for 30-60 $\mathrm{min}$ in ethanol $(10 \mathrm{~mL})$ containing conc. $\mathrm{HCl}(2 \mathrm{~mL})$. The reaction mixture poured in water $(300 \mathrm{~mL})$ with vigorous agitation, afforded the target compound, which was collected by filtration and crystallized from ethanol. TLC eluent $\mathrm{CH}_{3} / \mathrm{MeOH}=10 / 1$.

$N$-(4-Methylbenzo[d] thiazol-2-yl)-4-nitrobenzenesulfonamide (10). Yield: $86.8 \%$. M.p.214$215^{\circ} \mathrm{C}$. IR (KBr): $3100(\mathrm{NH}), 1338,1147\left(\mathrm{SO}_{2}\right) \mathrm{cm}^{-1} .{ }^{1} \mathrm{H}$ NMR (DMSO-d 6 , ppm): 8.37 (d, 2H, $J=8.7$, H-3', H-5'); 8.10 (d, 2H, J=9.0, H-2', H-6'); 7.64 (dd, 1H, J=1.8, J=8.7, H-7); 7.21-7.18 (m, 2H, H-5, H-6); 2.39 (s, 3H, $\mathrm{CH}_{3}$ ). Anal. Calcd. for $\mathrm{C}_{14} \mathrm{H}_{11} \mathrm{~N}_{3} \mathrm{O}_{4} \mathrm{~S}_{2}$ (349): C, 48.13; H, 3.17; N, 12.03; S, 18.35\%. Found: C, 48.12; H, 3.19; N, 12.05; S, 18.37\%. 
$\boldsymbol{N}$-(6-Ethoxybenzo[d] thiazol-2-yl)-4-nitrobenzenesulfonamide (11). Yield: 31\%. M.p.240-241 ${ }^{\circ} \mathrm{C}$. IR (KBr): $3107(\mathrm{NH}), 1342,1149\left(\mathrm{SO}_{2}\right) \mathrm{cm}^{-1} .{ }^{1} \mathrm{H}$ NMR (DMSO-d 6 , ppm): $8.36(\mathrm{~d}, 2 \mathrm{H}$, $J=9.0, \mathrm{H}-3$ ' $+\mathrm{H}-5$ '); 8.08 (d, 2H, $J=9.0, \mathrm{H}-2$ ' + H-6'); 7.47 (d, 1H, $J=2.7, \mathrm{H}-7$ ); 7.23 (d, 1H, $J=9.0, \mathrm{H}-4) ; 6.99$ (dd, $1 \mathrm{H}, J=2.7, J=9.0, \mathrm{H}-5) ; 4.03$ (q, 2H, $\left.J=7.2, \mathrm{OCH}_{2} \mathrm{CH}_{3}\right) ; 1.32$ (t, $3 \mathrm{H}, J=7.2$, $\mathrm{CH}_{3}$ ). MS: 379 (M+, 100), 316 (12), 315 (62), 286 (13), 195(9), 194 (62), 193 (85), 166 (43), 165 (600, 32 (37\%). Anal. Calcd. For $\mathrm{C}_{15} \mathrm{H}_{13} \mathrm{~N}_{3} \mathrm{O}_{5} \mathrm{~S}_{2}$ (379): C, 47.49; H, 3.45; N, 11.07; S, 16.9\%. Found: C, 47.47; H, 3.46; N, 11.09; S, 16.7\%.

$\mathbf{N}$-(6-Fluorobenzo[d] thiazol-2-yl)-4-nitrobenzenesulfonamide (12). Yield: $32.5 \%$. M.p. 265$266^{\circ} \mathrm{C}$. IR (KBr): $3110(\mathrm{NH}), 1342,1147\left(\mathrm{SO}_{2}\right) \mathrm{cm}^{-1} .{ }^{1} \mathrm{H}$ NMR (DMSO-d 6 , ppm): $8.36(\mathrm{~d}, 2 \mathrm{H}$, $J=8.7$, H-3'+ H-5'); 8.09 (d, 2H, $J=8.4$, H-2'+ H-6'); 7.79 (dd, 1H, $J=1.8, J=8.4$, H-7); 7.357.25 (m, 2H, H-4 + H-5). MS: M+ 335 (36), 334 (11), 271 (38), 270 (45), 225 (9), 223 (13), 196 (10), 150 (20), 149 (71), 121 (13), 104 (11), 96 (8), 63 (9), 40 (7), 32 (100). Anal. Calcd. for $\mathrm{C}_{13} \mathrm{H}_{8} \mathrm{FN}_{3} \mathrm{O}_{4} \mathrm{~S}_{2}$ (335): C, 46.56; H, 2.71; N, 12.53; S, 19.21\%. Found: C, 46.55; H, 2.73; N, $12.55 ; \mathrm{S}, 19.22 \%$.

$\mathbf{N}$-(6-Chlorobenzo[d] thiazol-2-yl)-4-nitrobenzenesulfonamide (13). Yield: 64\%. M.p. 276$277^{\circ} \mathrm{C}$. IR (KBr): $3101(\mathrm{NH}), 1340,1147\left(\mathrm{SO}_{2}\right) \mathrm{cm}^{-1} .{ }^{1} \mathrm{H}$ NMR (DMSO-d 6 , ppm): $8.37(\mathrm{~d}, 2 \mathrm{H}$, $J=8.7$, H-3'+ H- 5'); 8.09 (d, 2H, J=8.7, H-2'+ H-6'); 7.99 (d, 1H, J=1.8, H-7); 7.45 (dd, 1H, $J=1.5, J=8.7$, H-4); 7.30 (d, 1H, J=8.7, H-5). MS: M+303 (23), 302 (75), 174 (7), 129 (7), 127 (100), 111 (10), 100 (7), 85 (24), 59 (10). Anal. Calcd. for $\mathrm{C}_{13} \mathrm{H}_{8} \mathrm{ClN}_{3} \mathrm{O}_{4} \mathrm{~S}_{2}$ (369) : C, 42.22; $\mathrm{H}$, 2.18; N, 11.36: S, 17.34; Cl, 9.59\%. Found: C, 42.20; H, 2.16; N, 11.35; S, 17.33\%.

$\mathbf{N}$-(6-Chlorobenzo[d] thiazol-2-yl)-4-chlorobenzenesulfonamide (15). Yield: 60.5\%. M.p. 299$300{ }^{\circ} \mathrm{C}$. IR (KBr): $3095(\mathrm{NH}), 1322,1147\left(\mathrm{SO}_{2}\right) \mathrm{cm}^{-1} .{ }^{1} \mathrm{H}$ NMR (DMSO-d 6 , ppm): 7.97 (s, 1H, H-7); 7.84 (d, 2H, J=8.4, H-2'+ H-6'); 7.62 (d, 2H, J=8.4, H-3'+ H-5'); 7.42 (d, 1H, J=8.1, H4); 7.28 (d, 1H, H-5). MS: 360(M+, 19), 358 (25), 296 (13), 295 (17), 294 (20), 293 (22), 185 (36), 184 (16), 183 (97), 175 (20), 148 (20), 142 (12), 139 (21), 113 (32), 111 (100) 95 (10), 85 (8), 79 (9), 77 (8), 76 (18), 75 (55) , 69 (11), 64 (17), 63 (9), 62 (14), 51 (18), 50 (24), 45 (13), 44(11). Anal. Calcd. for $\mathrm{C}_{13} \mathrm{H}_{8} \mathrm{Cl}_{2} \mathrm{~N}_{2} \mathrm{O}_{2} \mathrm{~S}_{2}$ (358): Found: C, 43.46; H, 2.24; Cl, 19.74; N, 7.8; S, 17.85\%. Found: C, 43.48; H, 2.22; N, 7.81; S, 17.83\%.

\section{Microbiology}

\section{Antimicrobial activity evaluation}

The new sulfonamides were tested in vitro for their antimicrobial properties against the microorganisms listed in Tables 1 and 2 by using the serial double dilution method. ${ }^{26}$ Stock solutions of the compounds were prepared by dissolving them in dimethyl sulfoxide. Then, the solutions were diluted in the media (Tryptose Phosphate Broth for Streptococcus pyogenes, Mueller Hinton broth for other bacteria and Sabouraud liquid medium for fungi) so as to achieve concentrations of compound ranging from 0.001 to $100 \mu \mathrm{g} / \mathrm{mL}$. Ampicillin, sulfamethoxazole and miconazole, at the same concentrations of the text compounds, were used as standard 
antibacterial and antifungal drugs, respectively. Dimethyl sulfoxide was employed as solvent control. Bacteria were inoculated at the concentration of $5 \times 10^{4} \mathrm{CFU} / \mathrm{mL}$ and fungi at $1 \times 10^{3}$ $\mathrm{CFU} / \mathrm{mL}$. After an incubation period of $24 \mathrm{~h}$ at $37^{\circ} \mathrm{C}$ (bacteria) and of $48 \mathrm{~h}$ at $30^{\circ} \mathrm{C}$ (fungi), the minimum inhibitory concentrations ( $\mathrm{MIC}, \mu \mathrm{g} / \mathrm{mL}$ ) were detected as the lowest concentrations of compound that didn't show microbial growth.

The minimum bactericidal concentrations $(\mathrm{MBC}, \mu \mathrm{g} / \mathrm{mL}$ ) and the minimum fungicidal concentrations (MFC, $\mu \mathrm{g} / \mathrm{mL}$ ) were determined by subculturing on fresh medium $100 \mu \mathrm{L}$ of liquid from each suspension remaining clear and incubating the samples obtained at $37^{\circ} \mathrm{C}$ for 24 $\mathrm{h}$ (bacteria) or at $30^{\circ} \mathrm{C}$ for $48 \mathrm{~h}$ (fungi). MBC and MFC values represent the lowest concentration of drug needed for the reduction of the initial inoculum of $99.9 \%$.

All the experiments were performed in triplicate and the reported results were obtained from three independent measurements.

\section{Synergism studies}

The effect of combinations of the active sulfonamides with trimethoprim (Sigma, Milano, Italy) against Bacillus subtilis ATCC 6633 and Staphylococcus aureus ATCC 25923 was detected in vitro by using the paper strip diffusion method and the checkerboard titration technique. ${ }^{11,27}$ The antimicrobial combination of sulfamethoxazole with trimethoprim was used as positive standard control. The solutions of the standard drugs were prepared in water by adding the minimal amount of $2.5 \mathrm{M} \mathrm{NaOH}$ (for sulfamethoxazole) or $0.05 \mathrm{M} \mathrm{HCl}$ (for trimethoprim) to dissolve them.

In the paper strip diffusion technique, the effectiveness of the drug interaction was determined by comparing the zones of inhibition of the bacterial growth produced by sulfonamides alone with those produced in the presence of trimethoprim. Iso-Sensitest Agar plates were inoculated by fresh cultures of the microorganism to be tested suspended in molten top agar at the concentration of $5 \times 10^{5} \mathrm{CFU} / \mathrm{mL}$ to produce confluent growth. Filter paper strips (40 mm long, 3 $\mathrm{mm}$ wide) were impregnated with $25 \mathrm{~mL}$ of solutions of the sulfonamides or trimethoprim at concentrations, respectively, slightly lower than or equal to MICs and placed on the agar surface at right angles to one another. The plates were incubated at $4^{\circ} \mathrm{C}$ for $4 \mathrm{~h}$ to allow the drugs to diffuse into the agar medium and, then, transferred at $37^{\circ} \mathrm{C}$ for $18 \mathrm{~h}$. The combined effect of the sulfonamides with trimethoprim was examined by observing the inhibition halos produced by the substances alone and at the junction of the filter papers and by comparing them with those produced by sulfamethoxazole with trimethoprim. Synergistic interactions are evidenced by the presence of an increased inhibition zone at the junction point, as shown for the combination sulfamethoxazole-trimethoprim. On the contrary, no enhanced halos result for additive or indifferent interactions, while truncated zones of inhibition reveal antagonism.

As regards the checkerboard titration technique, sulfonamides were tested at concentrations ranging from 0.15 to $100 \mu \mathrm{g} / \mathrm{mL}$ and trimethoprim from 0.0003 to $3 \mu \mathrm{g} / \mathrm{mL}$. The checkerboard consisted of columns containing decreasing concentration of sulfonamides and of rows containing increasing concentrations of trimethoprim, so that drug-containing solutions can be 
mixed to produce all possible combinations of compound concentrations in the range of the dilutions used. The inoculum of the bacterial suspension added to each well was $5 \times 10^{4}$ bacteria $/ \mathrm{mL}$. The wells were incubated at $37^{\circ} \mathrm{C}$ for $24 \mathrm{~h}$ and the MICs of the sulfonamides and trimethoprim alone and combined were read. The effect of the studied combinations was expressed by the fractional inhibitory concentration (FIC) of each tested compound (S, sulfonamides; T, trimethoprim). The FIC indices (FICI) for the most effective combinations were then calculated by summing the separate FIC values of each sulfonamide and trimethoprim:

$$
\mathrm{FICI}=\mathrm{FIC}_{\mathrm{S}}+\mathrm{FIC}_{\mathrm{T}}
$$

$\mathrm{FIC}_{\mathrm{S}}=\mathrm{MIC}$ of each sulfonamide in combination / MIC of each sulfonamide alone $\mathrm{FIC}_{\mathrm{T}}=\mathrm{MIC}$ of trimethoprim in combination / MIC of trimethoprim alone.

Drug interactions are defined as synergistic when the FIC index is $\leq 0.5$, additive when the FIC index is $>0.5$ and $\leq 1$, while values $>1$ and $<4$ are classified indifference and values $\geq 4$ antagonism. ${ }^{28}$

The results were summarized graphically on the isobolograms constructed taking along the $\mathrm{x}$ axis the FIC of trimethoprim and along the y-axis the corresponding FIC values of each sulfonamide. The isobolograms were constructed by connecting with a line (isobol) the series of points generated for each drug combination. Synergistic interaction is diagrammed as concave isobol, additive effect as straight line and antagonism as a convex isobol.

All tests were performed in triplicate and the results were confirmed by three separate experiments.

\section{References}

1. Srivastava, P. N.; Rai, S. K. Eur. J. Med. Chem. Chim. Ther. 1980, 15, 274.

2. Bhargava, P. N.; Nair, M.G. R. J. Indian Chem. Soc. 1957, 34, 42.

3. Srivastava, P. K.; Srivastava, P. N. J. Med. Chem. 1970, 13, 304.

4. Lakhan, R.; Rai, B. J. Il Farmaco, Ed. Sci. 1986, 41, 788.

5. Geronikaki, A.; Theophilidis, G. Eur. J. Med. Chem. 1992, 27, 709.

6. Vicini, P.; Amoretti, L.; Chiavarini, M.; Impicciatore, M. Il Farmaco 1990, 45, 933.

7. Klose, N.; Niedbolla, K.; Schwartz, K.; Bottcher, I . Arch. Pharm. 1983, 316, 941.

8. Satsangi, R. K.; Zaidi, S. M.; Misra, V. C. Pharmazie 1983, 38, 341.

9. Gadad, A. K.; Mahajanshetti, C. S.; Nimbalkar, S.; Raichurkar, A. Eur . J. Med. Chem. 2000, 35(9), 853.

10. Misra, V. S.; Saxena, V. K.; Srivastava, R. J. Indian Chem. Soc. 1982, 59, 781.

11. Zani, F.; Vicini, P. Arch. Pharm. 1998, 331, 219.

12. Maren, T. H. Ann. Rev. Pharmacol. Toxicol. 1976, 16, 309.

13. Supuran, C. T.; Scozzafava, A.; Jurca, B. C.; Iiies, M. A. Eur. J. Med. Chem. 1998, 33, 83.

14. Renzi, G.; Scozzafava, A.; Supuran, C. T. Bioorg. Med. Chem. Lett. 2000, 10(7), 673. 
15. Li, J. J.; Anderson, D.; Burton, E. G.; Cogburn, J. N.; Collins, J. T.; Garland, D. J.; Gregory, S. A.; Huang, H. C.; Isakson, P. C.; Koboldt, C. M.; Logusch, E. W.; Norton, M. B.; Perkins, W. E.; Reinhard, E. J.; Seibert, K.; Veenhuizem, A. W.; Zang, Y.; Reitz, D. B. J. Med. Chem. 1995, 38, 4570.

16. Yoshino, H.; Ueda, N.; Niijma, J.; Sugumi, H.; Kotake, Y.; Koyanagi, N.; Yoshimatsu, K.; Asada, M.; Watanabe, T.; Nagasu, T.; Tsukahara, K.; Lijima, A.; Kitoh, K. J. Med. Chem. 1992, 35, 2496.

17. Newberry, G.; Viaud, P. GB Patent $51727219400125,1940$.

18. Xu, X.; Weitzberg, M.; Keyes, R. F.; Li, Q.; Wang, R.; Wang, X.; Zhang, X.; Frevert, E. U.; Camp, H. S.; Beutel, B. A.; Sham, H. L.; Gu, Y. G.. Bioorg. Med. Chem. Lett. 2007, 17(6), 1803.

19. Sprague, J. M.; Kissinger, L. W. J. Am. Chem. Soc. 1941, 63, 578.

20. Barf, T.; Emond, R.; Kurz, G.; Vallgarda, J.; Nilsson, M. PCT Int. Appl. CODEN: PIXXD2 WO $2001090090,2001$.

21. Tseng, C. K. Magn . Reson. Chem. 1987, 25(2), 105.

22. Patel, N. B.; Rathod, R. D. Int. J. Chem. Sc. 2006, 4(3), 569.

23. Neidlein, R.; Kruell, H. Archiv der Pharmazie und Berichte der Deutschen Pharmazeutischen Gesellschaft 1971, 304(10), 763.

24. Anand, N.; Remers, W. A. In Burger's Medicinal Chemistry and Discovery; Abraham, D. J. Ed.; 5th Edn.; Wiley and Sons: New York, 2003; Vol. 5, pp 557-582.

25. Colglazier, M. C. J. Lab. Clin. Med. 1950, 35, 875.

26. Jorgensen, J. H., Turnidge, J. D. In Manual of Clinical Microbiology; Murray, P. R., Baron, E. J.; Pfaller, M. A.; Tenover, F. C.; Yolken, R. H. Eds.; American Society of Microbiology: Washington, DC, 1999; pp 1526-1554 and 1640-1652.

27. Eliopoulos, G. M.; Moellering, R. C. Jr. In Antibiotics in Laboratory Medicine; Lorian, V. Ed.; Williams \& Wilkins: Baltimore, 1991; pp 432-492.

28. Meletiadis, J.; Meis, J. F. G. M.; Mouton, J. W.; Verweij, P. E. Reviews in Medical Microbiology 2002, 13, 101. 